\title{
Web Quality Features Impact on Customer Satisfaction
}

The Journal of Educational Paradigms 2020, Vol. 02(02) 120-124

(C) Authors

ISSN (Print): 2709-202X

ISSN (Online): 2709-2038

DOI: $10.47609 / 0202022020$

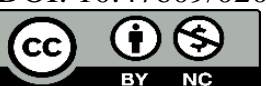

\author{
Waqas Zaki ${ }^{1}$, Waleed Bin Khalid ${ }^{2}$, Abdul Samad Bhatti ${ }^{3}$
}

\begin{abstract}
Online shopping is worldwide and becoming more popular phenomena nowadays. It is now a better option for customers because it is more comfortable and provides various options than conventional ones. So, the customer's satisfaction in online shopping is becoming more important and challenging for online retailers nowadays. Customer satisfaction is how much the customer is happy and fulfilled with an online retailer's products and services. In this research, the researcher used a survey method of distributing questionnaires to 270 respondents, using a random sampling technique. The research findings showed that achieving customer satisfaction the quality of a website plays an important role. It moves customer satisfaction negatively and positively as the study explains the customers' satisfaction's impact on website quality. In the future, it will help online retailers develop a website and know more about the customer behavior towards online shopping. It may help an online retailer determine how to improve its products and services and overcome the upcoming demands of customers satisfyingly in the future.
\end{abstract}

Keywords: Customer satisfaction, Online shopping, Website quality, Online retailer.

The Business-to-consumer Electronic-commerce is commerce in which both sellers and customers purchase online using the internet. As an emerging era of $\mathrm{B} 2 \mathrm{C}$, e-commerce in the public gives rise to the rapid worldwide growth of online retailing. In this context, multiple studies have been conducted to understand what makes online customers purchase online satisfyingly and to what extent the website's quality plays a role in customer satisfaction. Therefore, the factors that drive customers' satisfaction and their choice are important to understand for online retailers (Devaraj, Fan, \& Kohli, 2002). For online retailers, the customer satisfaction is becoming more challenging nowadays to meet the customer's non-purchase needs than conventional retailers. Customer satisfaction results in increased profits and more widespread through word of mouth. During the purchasing stages, the customer's experience is the consequence of customer's satisfaction (Chang, Wu, \& Chun, 2011).

Theoretically, it presents a research opportunity to investigate that in $\mathrm{B} 2 \mathrm{C}$ e-commerce, how much the customer requirement and factors affecting customer's satisfaction is important for online retailers. Any business needs to attract new customers and maintain their old customers (Xiaoying, Ling, \& Liu, 2012).In the e-commerce world, measuring the customer's opinions, the customer satisfaction is used (Delone \& McLean, 2003). The objective is to examine how the website quality affects the customer's satisfaction. The findings show that the emerging era of B2C e-commerce demands it improved the overall quality of the website. The online retailer is hidden in online shopping, so the intermediary between customer and online retailer is the website. Influencing the customer satisfaction, the website quality plays a vital role. The website quality is the most important factor for increasing the customer satisfaction level. The website is an intermediate between customer and online retailer, and it connects the customer with an online retailer. The research shows that influencing customer's satisfaction, and an important role was played by service quality than system and information quality (Noronha \& Rao, 2017). The website is the first impression of the online retailer towards the customer. So online retailer has to be more focused on its website quality and develop visually appealing websites for customers. It is the same as in conventional buying the customer first visit the shop then decide to make a purchase. If the shop is not appealing and does not satisfy the customer, the customer will not purchase. The website is also the online retailer's optical shop where they display their products and their information and make offers to attract the customer. This study will help online retailers know what extent the website quality affects the customer's satisfaction while developing their website according to the customer's needs.

\section{Literature Review}

In the era of e-commerce and marketing studies, the customer satisfaction and its feedback are prevalent research topics to discuss (Yoon, 2010). Customer satisfaction is the relationship of customer's expectation towards experience. When a customer's expectation meets or exceeds the experience, then the customer is satisfied. The satisfied customers make repurchases because they think that they will receive satisfying service again. It is profitable for the online retailer when customers become loyal. In other cases, if the customer's expectation does not meet the experience, they will be disappointed and never make a repurchase again. The online retailer needs to make its customers satisfied. It raises the e-loyalty and repurchases. The dissatisfied customer never recommends others also to purchase because of its bad experience. Dissatisfaction may be due to late delivery, low quality of the product. Trust causes the satisfaction, as customers are satisfied, they will feel free to share their details with the online retailer. The more the customer has trust more, and it has satisfaction. Talking about trust, in E-commerce, there are different types of people

${ }^{123}$ UCP Business School, Faculty of Management Studies, UCP, Pakistan. Corresponding author Email: zaki@ucp.edu.pk 
having diverse cultures have a different opinion about it. (Irantaj \& Giti, 2018). Website quality plays an important role and an important factor in focusing on online retailers. It affects the customer purchasing behavior. High quality websites provide the customer with an easy interface to purchase.

According to researchers, the website quality is the main driving force of customer satisfaction (Chang, Wu, \& Chun, 2011). This shows that website quality affects the customer's satisfaction. Hence, online retailers need to develop a website that satisfies the customer and attracts customers for repurchasing. The main driving force for customer satisfaction is website quality.

In research is has noticed that customer like to make a purchase from a website which is visually appealing and make a trust on the customer. The leading cause of repurchase is the customer's satisfaction, if, in their first purchase, the pleasure meet to their expectation or more than their expectation (Alam \& Yasin, 2010).In the case of repurchase, it not only depends on website quality, but several factors make a repurchase like delivery on time, product quality, payment method, etc. These all factors accumulate to make a repurchase. In the $\mathrm{B} 2 \mathrm{C}$ e-commerce era, the customer's satisfaction has critical importance due to the integration of Marketing and IS fields (Lin, 2010).

In the study, it is noticed that website quality and customer satisfaction have a relationship directly proportional to each other. Increasing website quality will improve the customer's satisfaction and decreasing the website quality will reduce the customer's satisfaction. When the customer logs into the system, the website is the first impression of an online retailer. The customer's satisfaction is an inner thing of customers. The website quality pursues the customer to buy if the website is visually appealing to the customer in a market. The website quality moves customer satisfaction in both a negative and positive way. Customers immediately switch to other websites if they are not satisfied with the website. Customer satisfaction can be affected negatively because of overloaded information (Noronha \& Rao, 2017). Overloaded information means that the website contains more specifications about the product. That can also change the purchase decision of the customers. There has been a minimal number of researches are done in the $\mathrm{B} 2 \mathrm{C}$ e-commerce era.

The literature reviewed shows the importance of customer satisfaction and website quality for an online retailer. Customer satisfaction is becoming more important and challenging for online retailers nowadays. Therefore, they are more focused on the factors affecting customer satisfaction. Loyalty is driven by satisfaction. When the customer is satisfied, he/she will make a repurchase. Creating loyal customers give a significant advantage to the online retailers in promoting their business (Bt, Ludinl, \& Cheng, 2014). Nowadays in the context of B2C e-commerce era, understanding the factors that

are affecting customer satisfaction, and customer's requirements are becoming more important and challenging for online retailers (Lin, 2010).

\section{Research Model}

Figure 1 is the model investigated in this research. The model consists of seven variables that are expected to measure the constant customer satisfaction.

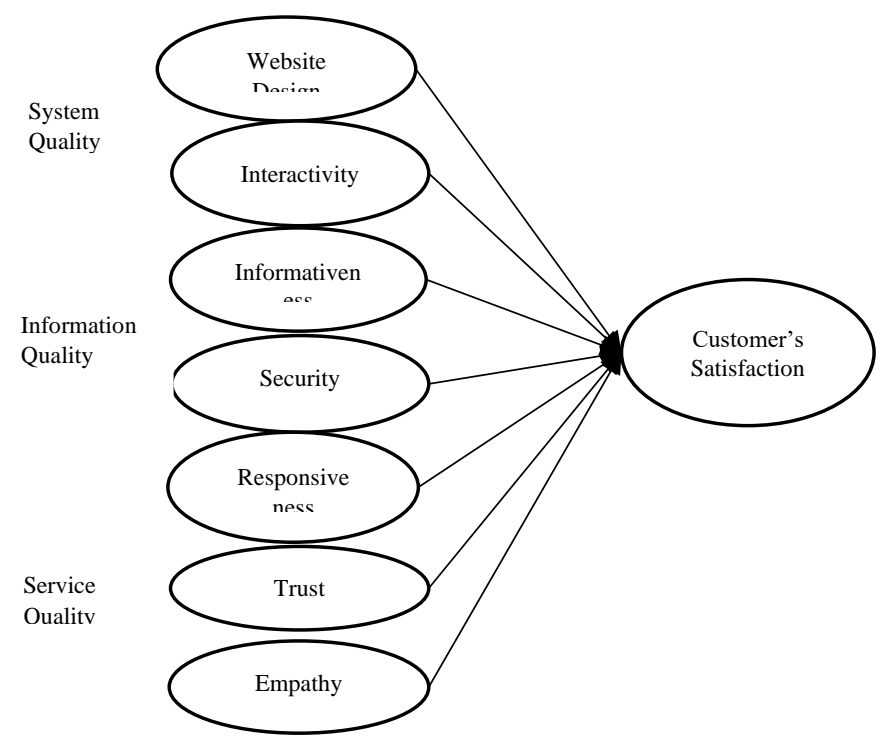

Figure 1: Conceptual Framework System Quality

System quality is an important point to focus on online retailers. It consists of website quality and interactivity. Defining the customer satisfaction service quality variables are very much significant (Agyapong, 2010). Website design is known as an architecture of the website, or in simple words, the way online retailer is representing its products online to attract customers. The online retailer is very much conscious about its website design because it is intermediate between the customer and online retailer and connects them. The visually appealing, the designed website attracts new customers (Ganguly \& Dash, 2009). The website is the virtual representation of an online retailer on the web. It is the first impression of the online retailer towards the customer, affecting the customer's satisfaction. The website and channel of interaction between the customer and online retailer (Hoffman \& Novak, 1996).

The customer perceived participation in a world based on ecommerce is the interactivity. It is how customers use the website shopping process, product searching, etc. It allows the online retailers to provide a more customized interface to their customers (Constantinides,, 2004). Interactivity is done by studying the customer purchase behaviour and making website design convenient to make customer satisfied. For online retailer website design and interactivity is the key to success (Liu \& Arnett, 2000).

\section{Information Quality}

Customer satisfaction estimates the value of an IS and influenced by Information Quality (Bharati \& Chaudhury, 2004). Informativeness and security are the two key factors used for measuring the Information Quality in this study. Informativeness is providing or displaying the product information to the customer. It directly affects customer satisfaction because some time providing less, or overload information may result in customers switch to another website. In case of less information, it may not satisfy the customer, and on other cases of overload information 
than adequate may cause difficulty for customers in finding desired information.

Security is the belief of the customer in that the payment he made is secure. It is because of cyber frauds that made people feel insecure about paying online. The security sometimes challenges satisfaction as the customer wants to buy a product and find that the desired one on the website, so the next question comes in the customer's mind if the payment method is secure. So, to make the payment secure some time, it becomes challenging for online retailers.

\section{Service Quality}

The online retailer's services and facilities to their customer make them buy satisfyingly and avoid the inconvenience. Increasing the service quality may result in more customer's loyalty and repurchase. To measure the quality of service provided by the online retailer in this study, we used three factors such as empathy, responsiveness, and trust.

Trust is the driving factor in customer satisfaction. Online customers are more conscious of trust, so online retailers always try to minimize factors causing trust issues as risk is high in online shopping because buyers and sellers both interact virtually (Ganguly \& Dash, 2009). Online retailers gain more trust by improving their services and making them trustworthy in the online market.

To decrease marketing expenses, increase profits, and gain the right word of mouth, online retailers have to build their trust in the market (Heskett \& Jr., 2010).

The responsiveness is the services given by online retailers to their customers when customers put the responsibility on the website. It affects customer satisfaction as if a customer uploads negative feedback on a website. The online retailers must respond to them and know the actual reason for negative feedback and make sure that they will not face it again in the future. This makes customer satisfy and increase repurchase; otherwise, they will switch to another website at next purchase for a product.

Table 1: Correlational Analysis

\begin{tabular}{llllll}
\hline & & SQD & SQI & IQI & IQS \\
\hline SQI & $\begin{array}{l}\text { Pearson } \\
\text { Correlation }\end{array}$ & $.593^{* *}$ & & & \\
IQI & $\begin{array}{l}\text { Pearson } \\
\text { Correlation }\end{array}$ & $.451^{* *}$ & $.521^{* *}$ & & \\
IQS & $\begin{array}{l}\text { Pearson } \\
\text { Correlation }\end{array}$ & $.393^{* *}$ & $.344^{* *}$ & $.387^{* *}$ & \\
SQR & $\begin{array}{l}\text { Pearson } \\
\text { Correlation }\end{array}$ & $.489^{* *}$ & $.456^{* *}$ & $.496^{* *}$ & $.414^{* *}$ \\
SQT & $\begin{array}{l}\text { Pearson } \\
\text { Correlation }\end{array}$ & $.451^{* *}$ & $.356^{* *}$ & $.425^{* *}$ & $.276^{* *}$ \\
SQE & $\begin{array}{l}\text { Pearson } \\
\text { Correlation }\end{array}$ & $.496^{* *}$ & $.450^{* *}$ & $.485^{* *}$ & $.337^{* *}$ \\
SCS & $\begin{array}{l}\text { Pearson } \\
\text { Correlation }\end{array}$ & $.509^{* *}$ & $.457^{* *}$ & $.548^{* *}$ & $.287^{* *}$ \\
\hline
\end{tabular}

The care and personalized attention are given by an online retailer to make their customer satisfy known as empathy. By empathy, the online retailer captures more place in a customer's mind and attracts them for repurchase, resulting in profitable outcomes for an online retailer (Lin, 2010). When customers share their reviews on the internet about its experience, the website gets positive word of mouth.

$\mathbf{H}_{1}$ : The convenient interface provided by the online retailer for its customers.

H2: The variety of purchasing decisions customers can make in online shopping.
H3: Making customers more informative about the product.

$\mathbf{H}_{4}$ : To the extent that payment made by a customer is secure.

H5: The services that make customers helpful are given by online retailers to their customers and include the response to the customer's actions.

H6: The trust mechanism provided by the online retailer to their customer to make them trustworthy.

H7: The extent to which the care and attention paid by the online retailer to their customer.

\section{Research Methodology}

Data contains by the study is taken by a self-administered questionnaire. The data is analysed through using cross-sectional study. The primary data was collected using a random sampling technique. Using the mono method, qualitative research has been done. The sample for this study is adapted from the population of persons who have ever purchased something online. The measuring instrument is combined using different sources. Eight items are measuring the system quality adapted from (Kim \& Lee, 2002). The information quality was measure using six items, and they are adapted from (Park \& Kim, 2003), and service quality was measure using eight items. They are adapted from (Delone \& McLean, 2003) (Kimery \& McCord, 2002). The customer satisfaction was measure using three items adapted from (Lin, 2010). The study uses a deductive approach. The 5-point Likerttype measuring instrument is used to measure all items in the study. For evaluation, the OLS method is applied.

\section{Data Analysis}

P-value is less than 0.05 than Co-efficient would be significant. We can see all the variables are showing the significant co-relation (Bryman \& Cramer, 1997). Proposed that "the Pearson's r between each pair of independent variables should not exceed 0.80; otherwise, the independent variables that show a relationship at or above 0.80 may be suggesting of exhibiting multicollinearity".

All the instruments used to measure in this study are predicting each other. The correlation is highly significant. As, adjusted from $\mathrm{R}$ square, it indicates that the model is improved but less than expesed Here SQT this studSefhat $\mathrm{R}$ square, which is 0.478 in correspondence to adjusted $\mathrm{R}$ square, is 0.464 . Less difference in $\mathrm{R}$ square and adjusted $\mathrm{R}$ square of the study shows that the betas are reliable. The high $\mathrm{R}$ square means variable is correlated and presents the reliability of beta.

Table 2: Model Summary

\begin{tabular}{lcccc}
\hline \multirow{2}{*}{ Model } & \multicolumn{4}{c}{ Statistics } \\
\cline { 2 - 5 } & R Square & $\begin{array}{c}\text { Adjusted R } \\
\text { Square }\end{array}$ & F Change & Sig. F Change \\
\hline 1 & .478 & .464 & 34.225 & .000 \\
\hline
\end{tabular}

\begin{tabular}{llll}
\multicolumn{1}{c}{.478} & \multicolumn{1}{c}{.464} & 34.225 & .000 \\
\cline { 1 - 2 } Table 3: Coefficient & Construct & & \\
\cline { 1 - 2 } Variable & Design & Beta & Sig. \\
\hline System Quality & Interactivity & 0.157 & 0.01 \\
\multirow{2}{*}{ Information Quality } & Informativeness & 0.04 & 0.52 \\
& Security & 0.22 & 0 \\
Service Quality & Responsiveness & -0.053 & 0.24 \\
& Trust & 0.199 & 0 \\
& Empathy & 0.06 & 0.24 \\
\hline
\end{tabular}

Dependent variable: Customer Satisfaction

The above table shows that four betas are significant. The Table 1.2 shows that the whole model is significant, which tells us that customer satisfaction can be predicted through web quality 
features. Furthermore, the investigation is also done to identify what factors have how much impact on customer satisfaction.

\section{System Quality}

The construct System Quality Design has beta 0.157 that is significant at 0.01 that shows the system quality is significant with the beta of design, contributing to customer satisfaction. Thus, all online retailers do not have to improve the system quality design because it contributes to customer satisfaction.

The construct System Quality Interactivity has beta 0.040, which is not significant at 0.52 that shows the system quality is not significant with the beta of interactivity. It is not contributing to the customer's satisfaction. Thus, all online retailers must improve the system quality interactivity and focus on making it significant because it is not contributing to customer satisfaction.

\section{Information Quality}

The construct Information Quality Informativeness has beta 0.220 that is significant at 0.01 that shows the information quality is significant with the beta of informativeness, and it is contributing to customer satisfaction. Thus, all online retailers do not have to improve the system quality informativeness because it is already contributing to customer satisfaction.

The construct Information Quality Security has beta -0.53 that is not significant at 0.24 that shows the information quality is not significant with the beta of security. It is not contributing to the customer satisfaction. The negative beta of information quality security shows that it is positively pointing to be a focus by the other online retailers. As customers want more security, and they are afraid of purchasing in online shopping. Thus, other online retailers have more need to improve information quality security and focus on making it significant. Because it is positively not contributing to customer satisfaction.

\section{Service Quality}

The construct Service Quality Responsiveness has beta 0.199 that is significant at 0.00 that shows the service quality is significant with the beta of responsiveness, and it is contributing to customer satisfaction. Thus, all online retailers do not have to improve the service quality responsiveness because it is already contributing to customer satisfaction.

The construct Service Quality Trust has beta 0.60, which is not significant at 0.24 that the information quality is not significant with the beta trust. It is not contributing to the customer's satisfaction. Thus, all online retailers must improve the service quality trust and also focus on this to make it significant because it is not contributing to customer satisfaction.

The construct Service Quality Empathy has beta 0.253 that is significant at 0.00 that shows the service quality is significant with the beta of empathy, and it is contributing to customer satisfaction. Thus, all online retailers do not have to improve the service quality empathy because it is already contributing to customer satisfaction.

\section{Conclusion}

The study findings show that online retailers must focus more on the website quality to increase the customer satisfaction. The factors like design, empathy, responsiveness, and informativeness were already contributing in increasing the customer's satisfaction. Customers of the E-commerce market are already satisfied with these factors. Website quality plays an essential role in increasing the customer satisfaction.

The study findings also show that factors like security, interactivity, and trust do not contribute to customer satisfaction. Customers of the E-commerce market are not satisfied with these factors. Online retailers need to pay more attention to these factors to enhance the customer satisfaction. Security is to focus more because the customer in the E-commerce market is not satisfied by the online retailers' security in the E-commerce market. So online retailers must provide more security and make their purchase safer that satisfies their customers.

Hence, the study highlights the areas like security, interactivity, and trust to be a focus by online retailers to increase the customer's satisfaction. The behavior of online customers may vary from country to country due to cultural changes. The sample was collected from the population of Lahore, Pakistan, so there might be a limited generalizability number.

\section{References:}

Agyapong, G. K. (2011). The effect of service quality on customer satisfaction in the utility industry-A case of Vodafone (Ghana). International Journal of Business and Management, 6(5), 203210.

Alam, S. S., \& Yasin, N. M. (2010). An investigation into the antecedents of customer satisfaction of online shopping. Journal of Marketing Development and Competitiveness, 5(1), 71-76.

Bharati, P., \& Chaudhury, A. (2004). An empirical investigation of decision-making satisfaction in web-based decision support systems. Decision support systems, 49(1), 61-69.

Bryman, A., \& Cramer, D. (1997). Quantitative data analysis with SPSS for Windows: A guide for social scientists. Routledge.

Bt, I. H., Ludinl, H., \& Cheng, B. L. (2014). Factors influencing customer satisfaction and e-loyalty: Online shopping environment among the young adults. Management Dynamics in the Knowledge Economy, 2(3), 462-465.

Chang, Y. F., Wu, H. Y., \& Chun, L. C. (2011). The critical factors impact on online customer satisfaction. Procedia Computer Science, 3(1), 276-281.

Constantinides, E. (2004). Influencing the online consumer's behavior: the Web experience. Internet research, 16-20.

Delone, W. H., \& McLean, E. R. (2003). The DeLone and McLean model of information systems success. Journal of Management Information Systems, 19(4), 9-30.

Devaraj, Fan, M., \& Kohli, R. (2002). Antecedents of B2C channel satisfaction and preference. Information Systems Research, 13(3), 316-333.

Ganguly, B., \& Dash, S. B. (2009). Website characteristics, Trust and purchase intention in online stores:-An Empirical study in the Indian. Information Science \& Technology, 6(2), 23-25.

Heskett, J. L., \& Jr., W. S. (2010). The service profit chain. Handbook of service science, 11.

Hoffman, D. L., \& Novak, T. P. (1997). A new marketing paradigm for electronic commerce. The Information Society, 13(1), 43-45.

Irantaj, \& Giti. (2018). Factors influencing customer satisfaction level in an e-commerce platform: a case study analysis of 
digikala in Iran. Istanbul Aydin university institute of social sciences.

Kim, J., \& Lee, J. (2002). Critical design factors for successful ecommerce systems. Behaviour \& Information Technology, 21(3), 185-199.

Kimery, K. M., \& McCord, M. (2002). Third-party Assurances: mapping the road to trust in E-retailing. Journal of Information Technology Theory and Application, 4(2), 7-8.

Lin, H. -F. (2007). The Impact of Website Quality Dimensions on Customer Satisfaction in the B2C E-commerce Context. Total Quality Management and Business Excellence, 18(4), 363-378.

Liu, C., \& Arnett, K. P. (2000). Exploring the Factors Associated with Web Site Success in the Context of Electronic Commerce. Information \& Management, 38(1), 23-33.
Noronha, A. K., \& Rao, P. S. (2017). Effect of Website Quality on Customer Satisfaction and Purchase Intention in Online Travel Ticket Booking Websites. Management, 7(5), 168-173.

Park, C. -H., \& Kim, Y. -G. (2003). Identifying key factors affecting consumer purchase behavior in an online shopping context. International journal of retail \& distribution management.

Xiaoying, G., Ling, K. C., \& Liu, M. (2012). Evaluating factors influencing customer satisfaction towards online shopping in China. Asian Social Science, 8(13), 40-41.

Yoon, C. (2010). Antecedents of customer satisfaction with online banking in China: The effects of experience. Computers in Human Behavior, 26(6), 1296-1304. 